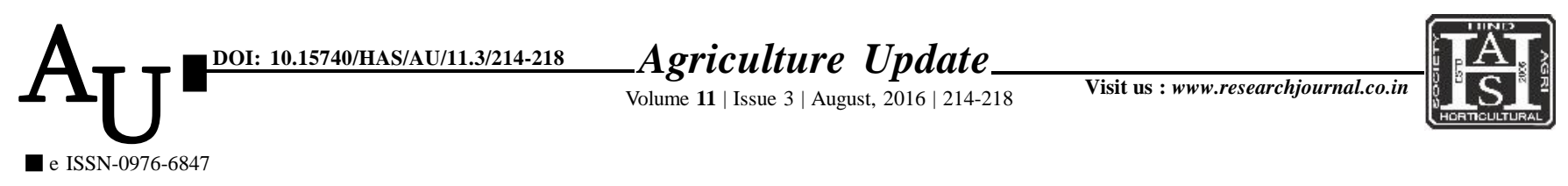

\title{
Research Article: Growth and instability analysis of onion and garlic in India
}

SOMANAGOUDA I. PATIL AND N.M. KERUR

Article Chronicle: Received :

23.05.2016;

Revised :

13.06.2016;

Accepted :

26.06.2016

KEY WoRds:

Growth rate, Instability index, Area, Production, Productivity

Author for correspondence :

\section{SOMANAGOUDA I.}

PATIL

Department of

Agribusiness

Management, College of Agriculture, University of Agricultural Sciences,

DHARWAD (KARNATAKA)

INDIA

Email: sipati14626@

gmail.com

See end of the article for authors' affiliations
SUMMARY : Onion (Allium cepa) and Garlic (Allium sativum) are important vegetable and spice commodities grown all over the world. These crops are grown in different parts of the country mainly by small and marginal farmers. Onion and garlic are used as spice, condiment and vegetable almost daily, because of special pungency, they have more value for seasoning a wide variety of dishes. Dehydrated flakes or powder are in great demand both in domestic and export markets. This study was mainly based on secondary data, the data were collected from National Horticulture Research and Development Foundation and National Horticulture Board amd analyzed using compound annual growth rate (CAGR) and instability index. The study revealed that for onion, area, production and productivity CAGR was highest in the last ten years. There was a positive growth in area and productivity of onion in India and Karnataka. Attempt has to be made in order to see that popularization of improved varieties, quality seed production and distribution, expansion of area in nontraditional pockets and contract production for export. Productivity of garlic expressed the negative trend which can be enhanced through improved cultural practices, distribution of planting materials, disease control measures, and selection of appropriate crop according to agro climatic conditions and irrigation facilities.

How to cite this article : Patil, Somanagouda I. and Kerur, N.M. (2016). Growth and instability analysis of onion and garlic in India. Agric. Update, 11(3): 214-218, DOI : 10.15740/HAS/AU/11.3/214-218. 